\title{
Pengaruh Harga dan Promosi Terhadap Loyalitas Pelanggan Pengguna Jasa Transportasi Online di Kota Medan
}

\author{
Salman Farisi \\ Qahfi Romula Siregar
}

\author{
Program Studi Manajemen, Universitas Muhammadiyah Sumatera Utara Medan, Indonesia \\ Jl. Kapten Muchtar Basri No. 3 Medan, Sumatera Utara 20217 \\ Email : salmanfarisi@umsu.ac.id
}

\begin{abstract}
Abstrak. Penelitian ini mempunyai tujuan untuk menguji dan mengetahui pengaruh harga dan promosi terhadap loyalitas pelanggan jasa transportasi online di Kota Medan mengingat tingkat permintaan jasa layanan transportasi online yang semakin meningkat dan penyedia layanan yang terus bermunculan. Pendekatan yang dilakukan dalam penelitian ini adalah pendekatan asosiatif. Populasi dalam penelitian ini adalah tak terhingga, dengan teknik accidental sampling, sehingga diambil sampel 100 orang. Jenis data yang dikumpulkan untuk mendukung variabel yang diteliti adalah data primer dan data sekunder. Teknik pengumpulan data yang digunakan yaitu wawancara (Interview), daftar pertanyaan (Questionaire) dan studi dokumentasi. Teknik analisis data dalam penelitian ini menggunakan analisis regresi linier berganda, uji t, uji F, dan koefisien determinasi. Pengolahan data menggunakan program software SPSS (statistic package for the social science) 20.00 for windows. Hasil penelitian menunjukkan bahwa secara parsial, masing-masing variabel Harga dan Promosi berpengaruh terhadap Loyalitas Pelanggan Gojek di Kota Medan dan secara simultan, variabel harga dan promosi berpengaruh terhadap loyalitas pelanggan Gojek di Kota Medan.
\end{abstract}

Kata Kunci : Harga, Promosi, Loyalitas Pelanggan

\begin{abstract}
This study aims to examine and determine the effect of price and promotion on customer loyalty in online transportation services in the city of Medan given the increasing demand for online transportation services and service providers that continue to emerge. The approach taken in this research is an associative approach. The population in this study was infinite, with accidental sampling technique, so that a sample of 100 people was taken. The type of data collected to support the variables studied are primary data and secondary data. Data collection techniques used were interviews (interviews), a list of questions (Questionaire) and study documentation. Data analysis techniques in this study used multiple linear regression analysis, $t$ test, $F$ test, and the coefficient of determination. Data processing using SPSS software program (statistical package for the social science) 20.00 for windows. The results showed that partially, each of the Price and Promotion variables affected the Gojek Customer Loyalty in Medan and simultaneously, the price and promotion variables influenced Gojek customer loyalty in the city of Medan
\end{abstract}

Keywords : Price, Promotion, Customer Loyalty

\section{PENDAHULUAN}

Laju pertumbuhan perekonomian khususnya di bidang transportasi semakin bersaing ketat, perusahaan-perusahaan transportasi terkhusus transportasi online semakin banyak mengeluarkan produk-produk layanan baru yang menjadi unggulan, bahkan dalam sebuah perusahaan melakukan diversifikasi layanan dengan mengeluarkan jenis-jenis dan keunggulan yang berbeda-beda. Perilaku masyarakat yang membutuhkan dan menginginkan layanan kualitas, harga serta dengan keunggulan yang ditawarkan pada tingkat harga yang kompetitif merupakan potensi yang harus diperhatikan produsen untuk mempengaruhi Loyalitas pelanggan pelanggan. Untuk maju dan berkembang dalam konsep pemasaran perusahaan harus 
mampu memahami kebutuhan dan keinginan pelanggan, dimana kepada merekalah nantinya produk tersebut akan dipasarkan.

Yayasan Lembaga Konsumen Indonesia (YLKI) telah melakukan survey online untuk pelayanan transportasi online. Survei dilakukan pada 5-16 April 2017 dengan melibatkan 4.668 responden, Aplikasi Gojek menduduki rating tertinggi dipilih konsumen, sebanyak 72,6 persen; kemudian Grab sebanyak 66, 9 persen; Uber digunakan oleh 51 persen dan terakhir My BlueBird sebanyak 4,4 persen. Kemudian ada beberapa keluhan yang disampaikan konsumen, yakni antara lain: pengemudi minta dibatalkan sebanyak 1.041 responden ( 22.3 persen), sulit mendapatkan pengemudi sebanyak 989 responden (21.19 persen), pengemudi membatalkan secara sepihak sebanyak 757 responden (16.22 persen), aplikasi map rusak/error sebanyak 612 responden (13.11 persen), berkurangnya kegiatan promosi 601 responden (13,02 persen), pengemudi tidak datang sebanyak 296 responden (6.34 persen), kondisi kendaraan kurang baik sebanyak 282 responden (6.04 persen), peningkatan harga sebanyak 275 (5,98 persen) ,pengemudi ugal-ugalan sebanyak 221 responden (4.73 persen), kendaraan bau asap rokok sebanyak 215 responden (4.61 persen), dan pengemudi merokok saat mengemudi sebanyak 35 responden (0.75 persen) (Wartakota, 12/5/2017).

Hasil di atas menunjukkan tingkat persaingan aplikasi penyedia jasa transportasi online dan juga ada beberapa keluhan yang disampaikan oleh pelanggan terkait pelayanan yang diberikan oleh jasa transportasi online tersebut, hal ini akan memberikan dampak bagi para pelanggan untuk tetap loyal terhadap jasa layanan transportasi online atau berpindah kembali kepada jasa transportasi konvensional.

Dalam mengkomunikasikan produk dan jasa kepada pelanggan melalui kegiatan promosi juga merupakan suatu hal penting. Promosi merupakan kegiatan yang dilakukan perusahaan untuk menonjolkan keistimewaan-keistimewaan produk dan membujuk pelanggan untuk membeli. Strategi promosi menggabungkan periklanan, penjualan perorangan, promosi penjualan dan publisitas menjadi suatu program terpadu untuk berkomunikasi dengan pembeli dan orang lain yang pada akhirnya akan mempengaruhi Loyalitas pelanggan (Basu Swastha dan Irawan, 2010, hal. 9). Perlu diketahui bahwa betapa bagusnya suatu produk bila pelanggan belum pernah mendengarnya dan tidak yakin terhadap produk tersebut, maka calon pelanggan tidak akan melakukan pembelian.

Di samping promosi, tinjauan terhadap harga juga semakin penting, karena setiap harga yang ditetapkan perusahaan akan mengakibatkan tingkat permintaan terhadap produk berbeda. Dalam sebagian besar kasus, biasanya permintaan dan harga berbanding terbalik, yakni semakin tinggi harga, semakin rendah permintaan terhadap produk. Demikian sebaliknya, semakin rendah harga, semakin tinggi permintaan terhadap produk. Oleh karena itu, penetapan harga yang tepat perlu mendapat perhatian yang besar dari perusahaan.

Harga adalah nilai suatu barang yang dinyatakan dalam uang (Alma, 2013). Penerapan harga jual berasal dari harga pokok tersebut sedangkan harga pokok barang ditentukan oleh berapa besar biaya yang dikorbankan untuk memperoleh atau untuk membuat barang itu. Harga dapat diartikan sebagai jumlah uang atau satuan moneter dan atau satuan aspek lain (non moneter) yang mengandung kegunaan tertentu yang diperlukan untuk mendapatkan suatu jasa. Perusahaan menetapkan harga karena berbagai pertimbangan, namun ada baiknya jika dalam penetapan harga tersebut disesuaikan juga dengan nilai, manfaat, dan Promosi. Selain itu, penetapan harga juga sangat penting untuk dilakukan mengemukakan bahwa harga adalah sejumlah uang (ditambah beberapa produk kalau mungkin) yang dibutuhkan untuk mendapatkan sejumlah kombinasi dari produk dan pelayanannya.

Jika jasa transportasi online tidak melakukan perbaikan, bukan tidak mungkin ke depan akan bermunculan produk layanan baru yang juga akan menyingkirkan produk jasa layanan 
transportasi online seperti sekarang ini sehingga persaingan harga dan promosi menjadi sebuah indikasi tersendiri bagi konsumen dalam menentukan tingkat loyalitasnya terhadap pengguna jasa layanan transportasi online di Kota Medan.

\section{LANDASAN TEORI}

\section{Loyalitas}

Loyalitas dapat diartikan dengan kesetian. Loyalitas yang dimaksud dalam penelitian ini adalah loyalitas pelanggan terhadap perusahaan. Dimana pelangan membeli sebuah produk atau jasa dari sebuah perusahaan, kemudian pelanggan tersebut setia (loyal) kepada produk atau jasa perusahaan tersebut. Menurut (Tjiptono, 2012), bahwa selama ini loyalitas pelanggan kerap kali dikaitkan dengan perilaku pembelian ulang. Keduanya memang berhubungan, namun sesungguhnya berbeda. Dalam konteks merek, misalnya loyalitas mencerminkan komitmen psikologis terhadap merek tertentu, sedangkan perilaku pembelian ulang semata mata menyangkut pembelian merek tertentu yang sama secara berulangkali (bisa dikarenakan memang karena satu - satunya merek yang tersedia, merek yang termurah dan sebagainya).

Menurut (Nurullaili \& Wijayanto, 2013) beberapa faktor yang mempengaruhi loyalitas pelanggan yaitu diantaranya promosi dan harga. Promosi merupakan aktivitas pemasaran yang berusaha menyebarkan informasi, mempengaruhi/membujuk, dan mengingatkan pasar sasaran atas perusahaan dan produknya agar bersedia menerima, membeli dan loyal pada produk yang ditawarkan perusahaan yang bersangkutan sedangkan harga selain merupakan jalan masuknya uang ke perusahaan, juga berhubungan dengan kualitas produk atau jasa. Perusahaan harus mampu menciptakan strategi penentuan harga yang tidak hanya memberi keuntungan bagi perusahaan, namun juga memuaskan pelanggannya.

Menurut (Griffin, 2002), loyalitas pelanggan dapat diukur dengan cara sebagai berikut:

1. Melakukan Pembelian Berulang secara teratur.

Bagaimana pelanggan melakukan pembelian produk secara berulang-ulang.

2. Membeli antar lini produk atau jasa

Pelanggan akan membeli produk lain yang ditawarkan oleh perusahaan.

3. Mereferensikan kepada orang lain

Pelanggan akan menawarkan atau menceritakan pada orang lain bahwa produk dari perusahaan sangat baik untuk dikonsumsi.

4. Menunjukan kekerabatan terhadap tarikan dari pesaing - pesaing Dimana pelanggan tidak terpengaruh kepada produk lain ketika perusahaan lain menawarkan produknya kepada pelanggan.

Dari empat indikator loyalitas pelanggan yang ada diatas, maka dapat diketahui bagaimana pelanggan dapat dikatakan loyal terhadap perusahaan. Pada umumnya pelanggan yang loyal tidak akan mudah dipengaruhi oleh perusahaan lain yang sejenis, dan pelanggan tersebut mereferensikan perusahaan kepada orang lain, seperti keluarga atau teman-temannya.

\section{Harga}

Menurut (Kotler \& Amstrong, 2011) menyatakan harga dalam arti yang sempit adalah jumlah yang ditagihkan atas suatu produk atau jasa. Lebih luas lagi, harga adalah jumlah semua nilai yang diberikan oleh pelanggan untuk mendapatkan keuntungan dari memiliki atau menggunakan suatu produk atau jasa. Menurut (Farida, Tarmizi, \& November, 2016), harga (price) adalah Elemen penting yang menempel pada sebuah produk. Harga menjadi kunci utama bagim konsumen untuk membeli barang, khususnya konsumen untuk membeli barang, khususnya konsumen kelas menengah ke bawah dalam pemasaran, penetuan harga bisa menjadi kekuatan untuk bersaing di dalam pasar 
Sedangkan menurut (Alma, 2013), harga adalah nilai dari suatu barang yang dapat dinyatakan dengan uang. Sehingga definisi harga adalah alat pengukur dasar sebuahsistem ekonomi karena harga mempengaruhi alokasifaktor-faktor produksi. Dan harga juga dapat didefinisikan sebagai jumlah uang yang dibutuhkan untuk memperoleh beberapa kombinasi sebuah produk dan pelayanan yang menyertainya.

Menurut (Kotler \& Amstrong, 2012), didalam variabelharga adabeberapa unsur kegiatan utama harga yang meliputi daftar harga, diskon, potonganharga, dan periode pembayaran. Menurut (Riyono \& Budiharja, 2016) ada empat indikator yang mencirikan harga yaitu: Keterjangkauan harga, kesesuaian harga dengan kualitasproduk, daya saing harga, kesesuaian harga dengan manfaat.

\section{Promosi}

Banyak pandangan telah diungkapkan dalam berbagai literatur tentang pengertian promosi, antara lain Menurut Ben M. Enis dalam (Riyono \& Budiharja, 2016) menyatakan : "Promosi itu adalah sejenis komunikasi yang memberi penjelasan yang meyakinkan calon pelanggan tentang barang dan jasa. Menurut (Kotler \& Amstrong, 2008) menyatakan promosi berarti aktifitas yang menyampaikan manfaat produk dan membujuk pelanggan untuk membelinya. Serta untuk memberitahu pelanggan tentang perusahaan dan produk-produknya. Menurut (Farida et al., 2016), promosi (promotion) adalah promosi sudah jelas alat utama dalam pemasaran sebuah produk. Promosi ini juga yang kemudian banyak menggerus keuangan perusahaan demi memperkenalkan produknya ke pasar.promosi dapat berupa iklan di media cetak maupun elektronik, brosur, baligho, dan sponsorship

Dari ketiga pendapat diatas promosi merupakan sebuah komunikasi khusus yang dilakukan penjual untuk dapat memberikan sebuah informasi dari keunggulan sebuah produk yang ditawarkan kepada pelanggan. Menurut (Kotler \& Amstrong, 2008) menyatakan ada 4 elemen promosi, yaitu meliputi:

1. Advertising, adalah menyampaikan pesan-pesan penjualan yang diarahkan kepada masyarakat melalui cara-cara yang persuasif yang bertujuan untuk menjual barang, jasa atau ide.

2. Sales Promotion, adalah keinginan menawarkan insentif dalam periode tertentu untuk mendorong keinginan calon pelanggan, para penjual atau perantara.

3. Public Relation - Publicity, artinya menciptakan "good relation" dengan public, agar masyarakat memilih image yang baik terhadap perusahaan.

4. Personal Selling, presentase langsung dalam percakapan dengan satu atau lebih prospek pelanggan untuk keuntungan dalam membuat penjualan.

\section{Kerangka Konseptual}

\section{Pengaruh Harga terhadap Loyalitas Pelanggan}

Menurut (Kotler \& Amstrong, 2008), harga merupakan faktor penentu utama permintaan pasar dan juga merupakan pendorong dalam mempengaruhi posisi persaingan. Pentingnya harga tergantung pada sifat pembeli. Semakin tinggi tingkat kesesuaian harga produk yang ditawarkan perusahaan menurut konsumen, maka semakin tinggi loyalitas pelanggan . Sebaliknya, semakin rendah tingkat kesesuaian harga produk yang ditawarkan perusahaan menurut konsumen, maka semakin rendah loyalitas pelanggan.

Dalam perdagangan bebas setiap perusahaan menghadapi persaingan yang ketat. Meningkatnya intensitas persaingan dan jumlah pesaing menuntut perusahaan untuk selalu memperhatikan kebutuhan dan keinginan pelanggan serta berusaha memenuhi harapan pelanggan dengan cara memberikan pelayanan yang lebih memuaskan daripada yang dilakukan 
oleh pesaing. Beberapa penelitian menunjukkan bahwa harga berpengaruh terhadap keputusan pembelian (Nasution, Putri, Pratami, \& Lesmana, Taufik, 2019); (Lubis, 2015); (Gultom, 2017); (Arif, 2016); dan (Fahmi, 2016), dimana keputusan pembelian ini akan berdampak terhadap loyalitas pelanggan.

\section{Pengaruh Promosi Terhadap Loyalitas Pelanggan}

Promosi merupakan segala bentuk komunikasi satu arah yang digunakan untuk menginformasikan, membujuk atau mengingatkan orang-orang tentang produk yang dihasilkan organisasi, individu ataupun rumah tangga untuk menciptakan pertukaran dalam pemasaran. Pelanggan akan setia dan loyal kepada perusahaan ketika perusahaan dapat memberikan tingkat promosi yang variatif, mudah diakses dan memberikan kepuasan. Beberapa penelitian menunjukkan bahwa promosi berpengaruh terhadap keputusan pembelian (Sanjaya, 2015); (Astuti \& Abdullah, 2018); (Arianty, 2016), dimana keputusan pembelian ini akan berdampak terhadap loyalitas pelanggan

\section{Pengaruh Promosi dan Harga Terhadap Loyalitas Pelanggan}

Promosi dan Harga merupakan dua variabel yang mempunyai hubungan dengan loyalitas pelanggan, promosi yang baik dengan penawaran-penawaran yang dapat memberikan kepuasan bagi pelanggan. Harga juga akan dapat mempengaruhi pelanggan dalam melakukan tindakan memutuskan membeli atau tidak terhadap sebuah produk, jika harga produk sesuai dengan kualitas yang diberikan maka loyalitas pelanggan akan semakin tinggi.

\section{METODE PENELITIAN}

Penelitian ini menggunakan pendekatan penelitian eksplanatori, yang bertujuan untuk menjelaskan hubungan sebab akibat antara variabel penelitian dan hipotesis pengujian (Nasution, Fahmi, Jufrizen, Muslih, \& Prayogi, 2020). Pendekatan yang digunakan adalah pendekatan asosiatif. Penelitian asosiatif menurut (Sugiyono, 2010) adalah penelitian yang dilakukan untuk menguji pengaruh antara dua variabel atau lebih. Penelitian dilakukan di seputaran pusat kota di Kota Medan. Populasi adalah sebagian kelompok individu atau sesuatu yang akan dijadikan objek penelitian, adapun jumlah populasi adalah tak terhingga. Target populasi dalam penelitian ini adalah para pelanggan yang menggunakan produk jasa transportasi online di Kota Medan. Sampel adalah bagian dari jumlah dan karakteristik yang dimiliki oleh populasi tersebut. Teknik pengambilan sampel yang digunakan adalah accidental sampling, (Sugiyono, 2010) accidental sampling adalah teknik penentuan sampel berdasarkan responden yang dapat dijumpai secara spontan. Adapun sampel yang diambil berdasarkan kuesioner yang diisi oleh responden atau pelanggan pengguna jasa transportasi online, yang dapat ditemui saat penelitian. Dalam penelitian ini sampel yang diambil adalah sebesar 100 responden yaitu pengguna jasa transportasi online di Kota Medan. Jenis data yang dikumpulkan untuk mendukung variabel yang diteliti adalah data primer dan data sekunder. Teknik pengumpulan data yang digunakan yaitu wawancara (Interview), daftar pertanyaan (Questionaire) dan studi dokumentasi. Teknik analisis data dalam penelitian ini menggunakan analisis regresi linier berganda, uji t, uji F, dan koefisien determinasi. Pengolahan data menggunakan program software SPSS (statistic package for the social science) 20.00 for windows.

\section{HASIL DAN PEMBAHASAN Uji Asumsi Klasik}

Bagian ini adalah menganalisis data yang berasal dari data-data yang telah dideskripsikan dari subbab sebelumnya (subbab deskripsi data). Data-data yang telah dianalisis dimulai dari 
asumsi-asumsi yang digunakan untuk suatu statistic tertentu, dilanjutkan dengan melakukan pengujian hipotesis untuk penarikan kesimpulan.

Dalam regresi linear berganda dikenal dengan beberapa asumsi klasik regresi berganda atau dikenal jugan dengan BLUE (Best Linear Unbias Estimation). Pengujian asumsi klasik secara sederhana bertujuan untuk mengidentifikasi apakah model regresi merupakan model yang baik atau tidak.

\section{Uji Normalitas}

Pengujian normalitas data dilakukan untuk melihat apakah dalam model regresi variabel dependen dan independennya memiliki distribusi normal atau tidak. Jika data menyebar di sekitar garis diagonal dan mengikuti arah garis diagonal maka model regresi memenuhi asumsi normalitas (Juliandi, Irfan, \& Manurung, 2014).

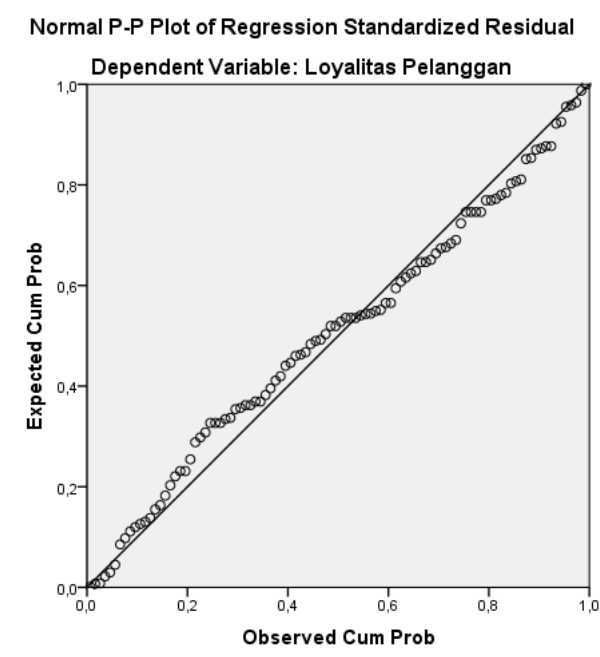

Gambar 1. Normalitas

Sumber : Pengolahan Data SPSS 21

Gambar di atas mengindikasikan bahwa model regresi telah memenuhi asumsi yang telah dikemukakan sebelumnya, sehingga data dalam model regresi ini cenderung normal.

\section{Uji Multikolinearitas}

Multikolinearitas digunakan untuk menguji apakah pada model regresi ditemukan adanya korelasi yang kuat antara variable independent. Cara yang digunakan untuk menilainya adalah dengan melihat nilai faktor inflasi barian (Variance Inflasi Factor/VIf), yang tidak melebihi 4 atau 5 .

Tabel 1. Hasil Uji Multikolinearitas

\begin{tabular}{|c|c|c|c|}
\hline \multicolumn{2}{|c|}{ Model } & \multicolumn{2}{|c|}{ Collinearity Statistics } \\
\hline & & Tolerance & VIF \\
\hline \multirow{3}{*}{1} & (Constant) & & \\
\hline & Harga & ,670 & 1,491 \\
\hline & Promosi & 670 & 1,491 \\
\hline
\end{tabular}

a. Dependent Variable: Loyalitas Pelanggan

Sumber : Pengolahan Data SPSS 21

Kedua variabel independent yaitu $\mathrm{X}_{1}$, dan $\mathrm{X}_{2}$ memiliki nilai VIF dalam batas toleransi yang telah ditentukan (tidak melebihi 4 atau 5), sehingga tidak terjadi multikolonieritas dalam variabel independen penelitian ini. 


\section{Uji Heteroskedastisitas}

Heteroskedastisitas digunakan untuk menguji apakah dalam model regresi, terjadi ketidaksamaan varians dari residual dari suatu pengamatan yang lain. Jika variasi residual dari suatu pengamatan ke pengamatan yang lain tetap, maka disebut homokedastisitas, dan jika varians berbeda disebut heteroskedastisitas. Model yang baik adalah tidak terjadi heteroskedastisitas (Juliandi, Irfan, \& Manurung, 2015). Dasar pengambilan keputusan adalah : jika pola tertentu, seperti titik-titik (point-point) yang ada membentuk suatu pola tertentu, maka terjadi heteroskedastisitas. Jika ada pola yang jelas, serta titik-titik (point-point) menyebar di bawah dan di atas 0 pada sumbu Y, maka tidak terjadi heteroskedastisitas.

Scatterplot

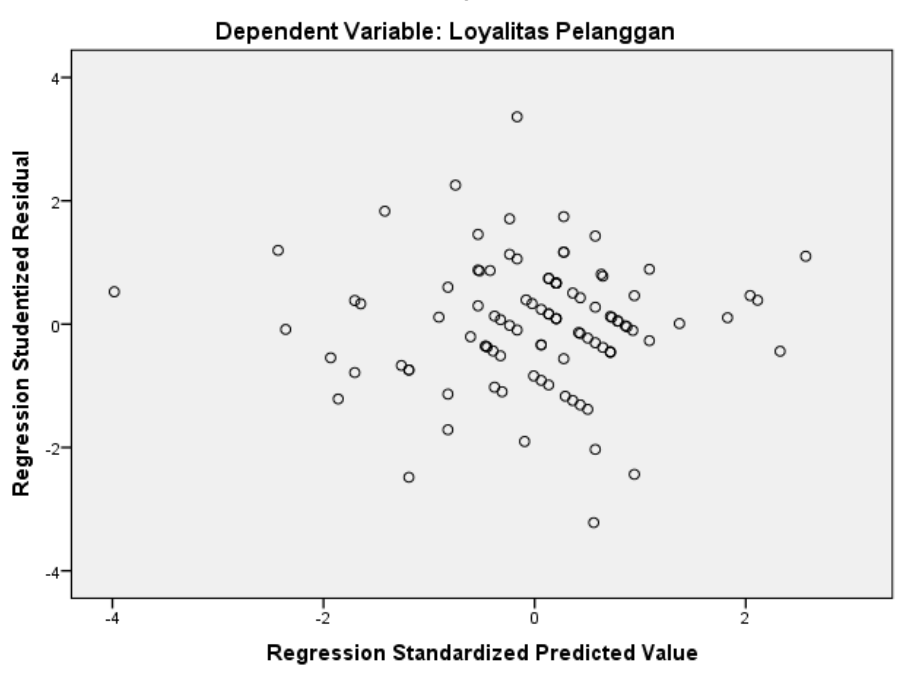

Gambar 2. Scatterplot

Sumber : Pengolahan Data SPSS 21

Gambar diatas memperlihatkan titik-titik menyebar secara acak, tidak membentuk pola yang jelas/teratur, secara tersebar baik diatas maupun di bawah angka 0 pada sumbu Y. Dengan demikian "tidak terjadi heteroskedastisitas" pada model regresi.

\section{Analisis Regresi Berganda}

Adapun regresi linear berganda bertujuan untuk melihat hubungan dan arah hubungan antar variabel independen tehadap variabel dependen dalam bentuk persamaan. Persamaan Regresi Berganda sebagai berikut :

$\mathrm{Y}=\mathrm{a}+\mathrm{bX} \mathrm{X}_{1}+\mathrm{bX} 2+\mathrm{e}$

Tabel 2. Hasil Regresi Linear Berganda

Coefficients $^{\mathrm{a}}$

\begin{tabular}{|c|c|c|c|c|c|c|}
\hline \multirow{2}{*}{\multicolumn{2}{|c|}{ Model }} & \multicolumn{2}{|c|}{$\begin{array}{c}\text { Unstandardized } \\
\text { Coefficients }\end{array}$} & \multirow{2}{*}{$\begin{array}{c}\text { Standardized } \\
\text { Coefficients } \\
\text { Beta }\end{array}$} & \multirow[t]{2}{*}{$\mathrm{t}$} & \multirow[t]{2}{*}{ Sig. } \\
\hline & & B & Std. Error & & & \\
\hline \multirow{3}{*}{1} & (Constant) & 10,003 & 2,088 & & 4,790 & ,000 \\
\hline & Harga &, 679 &, 096 &, 604 & 7,108 &, 000 \\
\hline & Promosi &, 130 & ,060 & ,186 & 2,192 & ,031 \\
\hline
\end{tabular}

Sumber : Pengolahan Data SPSS 21

Berdasarkan tabel di atas hasil dari proses yang menggunakan program software SPSS sebagai penghitungan, maka hasilnya sebagai berikut :

$\mathrm{Y}=10,003+0,679 \mathrm{X}_{1+0}, 130 \mathrm{X}_{2}+\mathrm{e}$ 
1. Konstanta mempunyai nilai regresi sebesar 10,003 , artinya jika variabel Harga $\left(X_{1}\right)$ dan Promosi $\left(\mathrm{X}_{2}\right)$ dianggap nol, maka ada kenaikan Loyalitas Pelanggan sebesar 10,003.

2. Harga $\left(\mathrm{X}_{1}\right)$ mempunyai koefisien regresi sebesar 0,679 dengan arah positif, artinya bahwa setiap kenaikan variabel Promosi sebesar 1\%, maka akan terjadi peningkatan Loyalitas Pelanggan sebesar 67,9\%

3. Promosi $\left(\mathrm{X}_{2}\right)$ mempunyai koefisien regresi sebesar 0,130 dengan arah positif, artinya bahwa setiap kenaikan variabel Promosi sebesar 1\%, maka akan terjadi peningkatan Loyalitas Pelanggan sebesar $13 \%$.

\section{Uji Hipotesis}

Uji hipotesis dilakukan untuk mengetahui pengaruh antara variabel independen terhadap variabel dependen, baik secara simultan maupun secara parsial.

\section{a. Uji t}

Tujuan dari Uji t adalah untuk melihat apakah ada hubungan yang signifikan atau tidak dalam hubungan antara variabel $\mathrm{X}_{1}$ dan $\mathrm{X}_{2}$ terhadap $\mathrm{Y}$. data tersaji pada tabel di bawah ini, adapun $\mathrm{t}$ tabel $=1,69$ (lihat tabel $\mathrm{t}$ untuk $\mathrm{N}=42$ ).

\section{Tabel 3. Uji t}

\begin{tabular}{|c|c|c|c|c|c|c|}
\hline \multirow[t]{2}{*}{ Model } & & \multicolumn{2}{|c|}{$\begin{array}{c}\text { Unstandardized } \\
\text { Coefficients }\end{array}$} & \multirow{2}{*}{$\begin{array}{c}\text { Standardized } \\
\text { Coefficients } \\
\text { Beta }\end{array}$} & \multirow[t]{2}{*}{$\mathrm{t}$} & \multirow[t]{2}{*}{ Sig. } \\
\hline & & $\mathrm{B}$ & Std. Error & & & \\
\hline \multirow{3}{*}{1} & (Constant) & 10,003 & 2,088 & & 4,790 &, 000 \\
\hline & Harga &, 679 &, 096 & ,604 & 7,108 & ,000 \\
\hline & Promosi & , 130 & ,060 & , 186 & 2,192 & ,031 \\
\hline
\end{tabular}

Sumber : Pengolahan Data SPSS 21

\section{Pengaruh Harga terhadap Loyalitas Pelanggan}

Hasil pengujian diperoleh nilai $\mathrm{t}$ untuk variabel Harga menunjukkan nilai $\mathrm{t}=7,108>\mathrm{t}$ tabel $=1,69$ dengan nilai signifikansi sebesar $=0,000<0,05$ yang berarti menunujukkan bahwa Harga memiliki pengaruh yang signifikan terhadap Loyalitas Pelanggan.

\section{Pengaruh Promosi terhadap Loyalitas Pelanggan}

Hasil pengujian diperoleh nilai $t$ untuk variabel promosi menunjukkan nilai $t$ hitung $=$ $2,192>\mathrm{t}$ tabel $=1,69$ dengan nilai signifikansi sebesar $=0,031<0.05$ dengan demikian berarti Promosi memiliki pengaruh yang signifikan terhadap Loyalitas Pelanggan.

\section{b. Uji F}

Uji $\mathrm{F}$ dilakukan untuk mengetahui dan menganalisi pengaruh variabel independen terhadap variabel dependen secara simultan. Hasil perhitungan Uji F disajikan pada tabel di bawah ini :

Tabel 4. Uji F

\begin{tabular}{llcrrrr}
\hline Model & & $\begin{array}{c}\text { Sum of } \\
\text { Squares }\end{array}$ & df & Mean Square & F & Sig. \\
\hline \multirow{2}{*}{1} & Regression & 333,047 & 2 & 166,523 & 54,595 &, $000^{\mathrm{b}}$ \\
\cline { 2 - 7 } & Residual & 295,863 & 97 & 3,050 & & \\
\cline { 2 - 7 } & Total & 628,910 & 99 & & &
\end{tabular}

Sumber : Pengolahan Data SPSS 21

Dari hasil pengolahana data di atas terlihat bahwa nilai Fhitung $=54,595>$ dari $\mathrm{F}$ tabel $=4,95$ (lihat tabel $\mathrm{F}$ untuk $\mathrm{N}=100$ ) dengan nilai probabilitas yakni sig adalah sebesar $0,000<$ 
0,05. Dengan demikian Harga dan Promosi secara simultan berpengaruh signifikan terhadap Loyalitas Pelanggan.

\section{Koefisien Determinasi (R-Square)}

Koefisien determinasi ini digunakan untuk mengetahui seberapa besar pengaruh variabel-variabel bebas memiliki pengaruh terhadap variabel terikatnya. Nilai koefisien determinasi ditentukan dengan nilai $R$ square.

Tabel 5. Koefisien Determinasi

\begin{tabular}{|c|c|c|c|c|c|c|}
\hline \multirow[t]{2}{*}{ Model } & \multirow[t]{2}{*}{$\mathrm{R}$} & \multirow[t]{2}{*}{ R Square } & \multirow{2}{*}{$\begin{array}{l}\text { Adjusted R } \\
\text { Square }\end{array}$} & \multirow{2}{*}{$\begin{array}{l}\text { Std. Error of } \\
\text { the Estimate }\end{array}$} & Change S & atistics \\
\hline & & & & & $\begin{array}{l}\text { R Square } \\
\text { Change }\end{array}$ & F Change \\
\hline 1 &, $728^{\mathrm{a}}$ & ,530 & ,520 & 1,74646 &, 530 & 54,595 \\
\hline
\end{tabular}

a. Predictors: (Constant), Pengalaman Kerja, Harga

b. Dependent Variable: Loyalitas Pelanggan

Sumber : Pengolahan Data SPSS 21

Dari hasil pengolahan data di atas terlihat bahwa nilai koefisien korelasi R Square sebesar 0,530, hal ini berarti Harga Dan Promosi secara bersama-sama mempunyai berpengaruh sebesar 53\% terhadap Loyalitas Pelanggan, sedangkan sisanya 47\% Loyalitas Pelanggan dipengaruhi oleh variabel-variabel lainnya yang tidak diteliti dalam penelitian ini.

Berdasarkan hasil penelitian maka peneliti melakukan pembahasan tentang pengaruh variabel independen terhadap variabel dependen.

\section{Pengaruh Harga Terhadap Loyalitas Pelanggan}

Harga yang murah dan sesuai pelayanan adalah harapan setiap pelanggan, apalagi di saat munculnya pesaing-pesaing baru, perusahaan memberikan ingkat harga yang jauh lebih murah kepada pelanggan lamanya, hal ini tentunya akan memberikan tingkat kesetiaan pelanggan terhadap perusahaan. Menurut (Tjiptono \& Chandra, 2016) harga bisa diartikan sebagai jumlah uang (satuan moneter) dan/atau aspek lain (non-moneter) yang mengandung utilitas/kegunaan tertentu yang deiperlukan untuk mendapatkan sebuah produk. Hasil penelitian ini menunjukkan bahwa variabel Harga menunjukkan nilai $\mathrm{t}=7,108>\mathrm{t}$ tabel $=1,69$ dengan nilai signifikansi sebesar $=0,000<0,05$ yang berarti menunujukkan bahwa Harga memiliki pengaruh yang signifikan terhadap Loyalitas Pelanggan, hal ini sejalan dengan penelitian terdahulu yang dilakukan (Kurniasih, 2012) menyatakan bahwa harga berpengaruh langsung terhadap loyalitas pelanggan, demikian juga dengan penelitian yang dilakukan oleh (Bulan, 2016) juga menyatakan bahwa harga berpengaruh terhadap loyalitas pelanggan.

\section{Pengaruh Promosi Terhadap Loyalitas Pelanggan}

Promosi merupakan segala bentuk komunikasi satu arah yang digunakan untuk menginformasikan, membujuk atau mengingatkan orang-orang tentang produk yang dihasilkan organisasi, individu ataupun rumah tangga untuk menciptakan pertukaran dalam pemasaran.

Pelanggan akan setia dan loyal kepada perusahaan ketika perusahaan dapat memberikan tingkat promosi yang variatif, mudah diakses dan memberikan kepuasan. Menurut (Kotler \& Amstrong, 2008) menyatakan promosi berarti aktifitas yang menyampaikan manfaat produk dan membujuk pelanggan untuk membelinya. Serta untuk memberitahu pelanggan tentang perusahaan dan produk-produknya. Hasil penelitian menunjukkan nilai $\mathrm{t}$ hitung $=2,192>\mathrm{t}$ tabel $=1,69$ dengan nilai signifikansi sebesar $=0,031<0.05$ dengan demikian berarti Promosi memiliki pengaruh yang signifikan terhadap Loyalitas Pelanggan, hal ini sejalan dengan 
penelitian terdahulu yang dilakukan oleh (Sarjita, 2018) menyatakan bahwa peningkatan promosi akan meningkatkan loyalitas pelanggan, demikian juga dengan penelitian yang dilakukan oleh (Soraya, 2015); (Azhar \& Jufrizen, 2017); (Azhar, Jufrizen, Prayogi, \& Sari, 2018); (R Radiman, Gunawan, Wahyuni, \& Jufrizen, 2018); (Radiman Radiman et al., 2018) yang menyatakan bahwa promosi berpengaruh terhadap loyalitas pelanggan.

\section{Pengaruh Harga dan Promosi Terhadap Loyalitas Pelanggan}

Promosi dan Harga merupakan dua variabel yang mempunyai hubungan dengan loyalitas pelanggan, promosi yang baik dengan penawaran-penawaran yang dapat memberikan kepuasan bagi pelanggan. Harga juga akan dapat mempengaruhi pelanggan dalam melakukan tindakan memutuskan membeli atau tidak terhadap sebuah produk, jika harga produk sesuai dengan kualitas yang diberikan maka loyalitas pelanggan akan semakin tinggi. Menurut (Tjiptono, 2012), bahwa selama ini loyalitas pelanggan kerap kali dikaitkan dengan perilaku pembelian ulang. Keduanya memang berhubungan, namun sesungguhnya berbeda. Hasil penelitian menunjukkan bahwa nilai Fhitung $=54,595>$ dari $\mathrm{F}$ tabel $=4,95$ (lihat tabel $\mathrm{F}$ untuk $\mathrm{N}=100$ ) dengan nilai probabilitas yakni sig adalah sebesar $0,000<0,05$. Dengan demikian Harga dan Promosi secara simultan berpengaruh signifikan terhadap Loyalitas Pelanggan, hal ini sejalan dengan penelitian terdahulu yang dilakukan oleh (Rotinsulu, Sumayku, \& Sambul, 2015) menyatakan bahwa harga dan promosi berpengaruh terhadap loyalitas pelanggan.

\section{KESIMPULAN}

Berdasarkan pada hasil analisis regresi linier berganda yang telah dilakukan pada penelitian ini, didapat kesimpulan bahwa secara parsial, masing-masing variabel Harga dan Promosi berpengaruh terhadap Loyalitas Pelanggan Gojek di Kota Medan. Secara simultan, variabel Harga dan Promosi berpengaruh terhadap Loyalitas Pelanggan Gojek di Kota Medan. Adapun saran-saran dalam penelitian ini adalah sebagai berikut : 1). Bagi perusahaan, diharapkan untuk memperhatikan dan meningkatkan hal-hal yang dapat mempengaruhi Harga dan Promosi dari pegawai, karena kedua variabel ini mampu meningkatkan Loyalitas Pelanggan dengan persentase yang cukup besar. Seperti memberikan tambahan promosi yang menarik dan bersaing dnegan pesaingnya kemudian diharapkan layanan perusahaan untuk mempertimbangkan kenaikan harga jasa layanan dibawah harga dari pesaingnya agar pelanggan dapat lebih memilih Gojek dibandingkan perusahaan lain. 2) Bagi peneliti selanjutnya, hendaknya menambahkan variabel-variabel independen lain serta menambah sampel penelitian untuk mendapatkan hasil yang lebih maksimal.

\section{DAFTAR PUSTAKA}

Alma, B. (2013). Manajemen Pemasaran \& Pemasaran Jasa (Revisi). Bandung: Alfabeta.

Arianty, N. (2016). Pengaruh Promosi dan Merek terhadap Keputusan Pembelian. Prosiding Dies Natalis Fakultas Ekonomi Dan Bisnis Universitas Sumatera Utara, 76-87.

Arif, M. (2016). Pengaruh Kualitas Pelayanan Dan Harga Terhadap Keputusan Pembelian Pada PT. Fastfood Indonesia Store KFC Raja Medan. Jurnal Ilmiah Maksitek, 1(1), 12-19.

Astuti, R., \& Abdullah, I. (2018). Pengaruh Kualitas Produk dan Promosi terhadap Keputusan Pembelian Pakaian di Usaha Mikro Kecil Menengah. Kumpulan Penelitian Dan Pengabdian Dosen, 1(1).

Azhar, M. E., \& Jufrizen, J. (2017). The Analysis of The Tourist Loyalty Determinant In the Area of Toba Lake. International Journal of Recent Scientific Research, 8(10), 2082620832. 
Azhar, M. E., Jufrizen, J., Prayogi, M. A., \& Sari, M. (2018). The Role of Marketing Mix and Service Quality on Tourist Satisfaction and Loyalty at Samosir. Journal of Tourism, (26).

Bulan, T. P. L. (2016). Pengaruh Kualitas Pelayanan dan Harga terhadap Loyalitas Konsumen pada PT. Tiki Jalur Nugraha Ekakurir Agen Kota Langsa. Jurnal Manajemen Dan Keuangan, 5(2), 592-602.

Fahmi, M. (2016). Pengaruh Harga Dan Kualitas Produk Terhadap Keputusan Pembelian Surat Kabar Tribun Medan. Jurnal Ilmiah Maksitek, 1(1), 65-72.

Farida, I., Tarmizi, A., \& November, Y. (2016). Analisis Pengaruh Bauran Pemasaran 7P Terhadap Kepuasan Pelanggan Pengguna Gojek Online. Jurnal Riset Manajemen Dan Bisnis, 1(1), 31-40.

Farisi, S. (2018). Pengaruh Citra Merek dan Kualitas Produk terhadap Keputusan Pembelian Sepatu Adidas pada Mahasiswa Universitas Muhammadiyah Sumatera Utara. In Prosiding: The National Conferences Management and Business (NCMAB) 2018 (pp. 689-705).

Griffin, J. (2002). Customer Loyalty: How to Earn It, How to Keep It (Revised). New York, United States: John Wiley \& Sons Inc.

Gultom, D. K. (2017). Pengaruh Harga Dan Kualitas Produk Terhadap Keputusan Pembelian Serta Dampaknya Pada Loyalitas Konsumen Handphone Blackberry Pada Mahasiswa Fakultas Ekonomi Universitas Muhammadiyah Sumatera Utara. Jurnal Ilmiah Kohesi, $1(1), 81-94$.

Juliandi, A., Irfan, I., \& Manurung, S. (2014). Metodologi Penelitian Bisnis, Konsep dan Aplikasi: Sukses Menulis Skripsi \& Tesis Mandiri. Medan: UMSU Press.

Juliandi, A., Irfan, I., \& Manurung, S. (2015). Metode Penelitian Bisnis : Konsep \& Aplikasi. In F. Zulkarnain (Ed.). Medan : UMSU PRESS.

Kotler, P., \& Amstrong, G. (2008). Prinsip-prinsip Pemasaran (Jilid I). Jakarta: Erlangga.

Kotler, P., \& Amstrong, G. (2011). Marketing: An Introduction (10th ed.). Upper Saddle River, NJ: Pearson Prentice Hall.

Kotler, P., \& Amstrong, G. (2012). Principles of Marketing. New Jersey: Pearson Prentice Hall.

Kurniasih, I. D. (2012). Pengaruh Harga Dan Kualitas Pelayanan Terhadap Loyalitas Pelanggan Melalui Variabel Kepuasan (Studi Pada Bengkel AHASS 0002-Astra Motor Siliwangi Semarang). Jurnal Administrasi Bisnis, 1(1), 37-45.

Lubis, A. A. (2015). Pengaruh Harga Dan Kualitas Produk Terhadap Keputusan Pembelian Surat Kabar Pada PT. Suara Barisan Hijau Harian Orbit Medan. Jurnal Ilmiah Manajemen Dan Bisnis, 16(2), 1-11. https://doi.org/10.30596/jimb.v16i2.949

Nasution, A. E., Putri, Pratami, L., \& Lesmana, Taufik, M. (2019). Analisis Pengaruh Harga, Promosi, Kepercayaan, dan Karakteristik Konsumen Terhadap Keputusan Pembelian Konsumen Pada 212 Mart di Kota Medan. Proseding Seminar Nasional Kewirausahaan, 1(1), 194-199. https://doi.org/https://doi.org/10.30596/snk.vlil.3594

Nasution, M. I., Fahmi, M., Jufrizen, J., Muslih, M., \& Prayogi, M. A. (2020). The Quality of Small and Medium Enterprises Performance Using the Structural Equation Model-Part Least Square (SEM-PLS). Journal of Physics: Conference Series, 1477(2020), 1-7. https://doi.org/10.1088/1742-6596/1477/5/052052

Nurullaili, N., \& Wijayanto, A. (2013). Analisis Faktor - Faktor yang Mempengaruhi Loyalitas Konsumen Tupperware (studi pada konsumen Tupperware di Universitas Diponegoro). Jurnal Administrasi Bisnis, 2(1), 89-97. https://doi.org/10.14710/jab.v2i1.5357

Radiman, R., Gunawan, A., Wahyuni, S. F., \& Jufrizen, J. (2018). The Effect of Marketing Mix, Service Quality, Islamic Values and Institutional Image on Students' Satisfaction and Loyalty. Expert Journal of Marketing, 6(2), 95-105. 
Radiman, R., Wahyuni, S. F., Jufrizen, J., Muslih, M., Gultom, D. K., \& Farisi, S. (2018). Effect Of Marketing Mix, Service Quality, And University Image On Student Loyalty. In Proceedings of the 1st International Conference on Economics, Management, Accounting and Business, ICEMAB 2018. https://doi.org/10.4108/eai.8-10-2018.2288715

Riyono, \& Budiharja, G. E. (2016). Pengaruh Kualitas Produk, Harga, Promosi Dan Brand Image Terhadap Keputusan Pembelian Produk Aqua Di Kota Pati. Jurnal Stie Semarang, $8(2), 92-121$.

Rotinsulu, E., Sumayku, S. M., \& Sambul, S. A. P. (2015). Pengaruh Harga, Produk Dan Promosi Terhadap Loyalitas Konsumen Big Jay Family Karaoke. Jurnal Administrasi Publik, 2(029), 1-14.

Sanjaya, S. (2015). Pengaruh Promosi Dan Merek Terhadap Keputusan Pembelian pada PT. Sinar Sosro Medan. Jurnal Ilmiah Manajemen Dan Bisnis, 16(02), 108-122.

Sarjita, S. (2018). Pengaruh Pelayanan, Harga dan Promosi Terhadap Loyalitas Pelanggan Pada Pengguna Go-Jek di Daerah Istimewa Yogyakarta. JBMA (Jurnal Bisnis, Manajemen Dan Akuntansi), 5(1), 76-92.

Soraya, I. (2015). Pengaruh Promosi Dan Ekuitas Merek Terhadap Loyalitas Konsumen Cipaganti Travel. Jurnal Komunikasi, 6(2), 11-23.

Sugiyono, S. (2010). Metode Penelitian Kualitatif Dan Kuantitatif. Medan: CV. Alfabet.

Tjiptono, F. (2012). Service Management Mewujdukan Pelayanan Prima. Yogyakarta: PT Andi Offset.

Tjiptono, F., \& Chandra, G. (2016). Service, Quality dan Satisfaction. (Andang, Ed.) (4th ed.). Yogyakarta: Andi Offset. 